\title{
THE DEAD-BOX PROTEIN CSHA FROM Staphylococcus aureus Mu 50 EXHIBITS RIBONUCLEASE ACTIVITY
}

\author{
HANH THI DIEU NGUYEN, NGOC AN NGUYEN, GIA BUU TRAN, TAN VIET PHAM \\ Institute of Biotechnology and Food Technology, Industrial University of Ho Chi Minh City \\ phamtanviet@iuh.edu.vn
}

\begin{abstract}
DEAD-box proteins play important roles in many RNA processes ranging from RNA synthesis to RNA decay. Furthermore, it has been reported that some bacterial DEAD-box proteins known to be components of the RNA degradosome do not cleave RNA substrates directly. However, the role of DEADbox proteins in RNA degradation is poorly understood. The present study demonstrated that the DEADbox protein CshA from the vancomycin-resistant Staphylococcus aureus strain Mu50 possesses RNA degradation activity, ribonuclease activity. Despite having RNA-dependent ATPase activity, CshA did not exhibit RNA helicase activity in vitro. Instead, CshA catalyzed the degradation of single-stranded RNAs of various duplex RNA substrates to form blunt-end RNA products. Thus, we suggest that the ribonuclease activity of the DEAD-box protein CshA may contribute to RNA remodeling in the bacterial RNA degradosome. To our knowledge, this study is the first to report that a DEAD-box protein from a pathogenic bacterium is implicated in multiple ATP-independent activity on RNA, such as degradation.
\end{abstract}

Keywords: Protein DEAD-box, CshA, ribonuclease, RNA helicase, Staphylococcus aureus.

\section{INTRODUCTION}

DEAD-box proteins are an important class of proteins that are widely distributed in both prokaryotes and eukaryotes. These proteins are characterized as putative RNA helicases and they are involved in nearly all RNA metabolic processes, including transcription, splicing, RNA transport, ribosome biogenesis, translation, and RNA decay [1-3]. DEAD-box proteins often contain nine conserved amino acid motifs; the DEAD motif itself is composed of four conversed amino acids (Asp-Glu-Ala-Asp). DEAD-box proteins possess numerous RNA-dependent activities such as RNA binding, RNA-dependent ATP hydrolysis, and ATP-dependent RNA unwinding. Because of their important roles in RNA metabolism, the functions of diverse DEAD-box proteins in cellular processes have been widely investigated. However, despite the diverse catalytic activities of DEAD-box proteins in RNA metabolism, detailed characterization of DEADbox proteins has been largely limited to descriptions of RNA helicase function in eukaryotes and Escherichia coli. To provide further understanding of the roles of DEAD-box proteins in nucleic acid metabolism, we investigated a DEAD-box protein from S. aureus strain Mu50. S. aureus is a prominent infectious bacterium that causes nosocomial and post-surgical wound infections. Isolated in 1997, Mu50 was one of the first methicillin-resistant $S$. aureus strains reported to have reduced susceptibility to vancomycin [4, 5]. Basic Local Alignment Search Tool (BLAST) protein searches of the S. aureus Mu50 genome database have identified two open reading frames (one with 506 amino acids and the other with 448 amino acids) that encode putative DEAD-box proteins predicted to be ATP-dependent RNA helicases $[6,7]$.

The 506 amino-acid DEAD-box protein, termed CshA, is involved in biofilm formation and cold adaptation. An S. aureus strain mutant for CshA displayed a cold-sensitive phenotype, with complete growth inhibition at room temperature [8]. Microbial biofilm formation is an important determinant of chronic infection in humans and is involved in a wide variety of staphylococcal infections in the body [9]. Biofilm formation increases antibiotic resistance and bacterial growth under extreme conditions such as high temperature, high salt concentration, UV radiation, and acidic conditions [10-12]. CshA has also been identified as a potential RNA helicase component of the RNA degradosome in bacteria [13]: CshA interacts with components of the RNA degradosome from the gram-positive model organism Bacillus subtilis and from S. aureus, and the S. aureus CshA interacts with phosphofructokinase, enolase, RNase Y, and RnpA, which is a protein subunit of RNase P [13]. However, detailed biochemical characteristics of CshA activity on RNA substrates are still unknown. 
In this study, we characterized the enzymatic activities of CshA from S. aureus Mu 50 on RNA substrates. As a putative ATPase-dependent RNA helicase, CshA was first examined for ATP hydrolysis and duplex RNA unwinding activity with various RNA substrates. Surprisingly, CshA exhibited no duplex RNA unwinding activity. However, CshA was found to have RNA degradation and unique enzymatic activity may account for the possible roles and functions of CshA in the RNA degradosome complex as well as in RNA metabolic processes in bacteria.

\section{MATERIALS AND METHODS}

\subsection{Cloning, expression, and purification of recombinant $\operatorname{Csh} A$}

The gene encoding the full-length (506 amino acids) DEAD-box helicase CshA (NCBI accession number Q99SH6.1) was amplified from genomic DNA from S. aureus strain Mu50 via the polymerase chain reaction using specific primers. The forward primer contained an NdeI restriction site and had the sequence 5'-CCCCATATGCAAAATTTTAAAGAACTAGGG-3', and the reverse primer contained an XhoI site and had the sequence 5'-CCCCTCGAGTTTTTGATGGTCAGCAAATG-3' (restriction sites are underlined). The PCR product was then subcloned between the NdeI and XhoI sites of the pET-22b vector (Novagen, Darmstadt, Germany). This construct contains an additional hexa-histidine tag (LEHHHHHH) at the C terminus for purification purposes. The recombinant plasmid was transformed into the $E$. coli Rosetta (DE3) strain (Novagen), and the cells were grown in a shaking incubator at $37{ }^{\circ} \mathrm{C}$ in Luria broth medium supplemented with $50 \mu \mathrm{g} / \mathrm{mL}$ ampicillin. Protein expression was induced by adding $0.5 \mathrm{mM}$ isopropyl-D1-thiogalactopyranoside when the cells reached an optical density at $600 \mathrm{~nm}$ of approximately 0.6 . The culture was then further incubated at $16{ }^{\circ} \mathrm{C}$ for $4 \mathrm{~h}$. The cultured cells were harvested, and the recombinant CshA was purified to homogeneity with $\mathrm{Ni}^{2+}$-chelating affinity chromatography and subsequent sizeexclusion chromatography, as described previously [14].

\subsection{Preparation of RNA oligonucleotides}

The single-stranded RNA fragments listed in Table 1 were chemically synthesized by Cosmo Genetech (Seoul, Korea). Oligonucleotides indicated with an asterisk (Table 1) were synthesized by in vitro transcription using T7 polymerase, as described previously [15]. Some of the RNA oligonucleotides were labeled with ${ }^{32} \mathrm{P}$ at the $5^{\prime}$ end using T4 polynucleotide kinase (10 U, Takara, Tokyo, Japan) and $1 \mu \mathrm{L}$ of $[\gamma-$ ${ }^{32} \mathrm{P}$ ] ATP $(3,000 \mathrm{Ci} / \mathrm{mmol}$, GE Healthcare, Piscataway, NJ, USA) in $20 \mu \mathrm{L}$ of reaction buffer containing 50 $\mathrm{mM}$ Tris- $\mathrm{HCl}, \mathrm{pH} 8.0,10 \mathrm{mM} \mathrm{MgCl}$, and $5 \mathrm{mM}$ dithiothreitol (DTT) at $37{ }^{\circ} \mathrm{C}$ for $1 \mathrm{~h}$. The labeled RNA strands were subsequently purified via phenol/chloroform extraction and subsequent ethanol precipitation. RNA duplexes (shown in Table 2) were prepared by annealing two RNA oligonucleotides as follows: the mixture of complementary oligonucleotides was heated at $85{ }^{\circ} \mathrm{C}$ for $5 \mathrm{~min}$ and then cooled slowly to room temperature.

Table 1. Sequences of single-stranded RNAs used in this study.

\begin{tabular}{|c|c|c|}
\hline No. & $\begin{array}{c}\text { Oligonucleotide } \\
\text { name/length (nts) }\end{array}$ & \multicolumn{1}{c|}{ Sequence $\left(\mathbf{5}^{\prime} \rightarrow \mathbf{3}^{\prime}\right)$} \\
\hline 1 & R0/47 * & GGAAAAUGUAAAUGACAUAGGCGCGCUGAAAGGGAGAAGUGAAAGUG \\
\hline 2 & BR0/47 & CACUUUCACUUCUCCCUUUCAGCGCGCCUAUGUCAUUUACAUUUUCC \\
\hline 3 & R1/25 & CGCGCCUAUGUCAUUUACAUUUUCC \\
\hline 4 & UR1/25 & GGAAAAUGUAAAUGACAUAGGCGCG \\
\hline 5 & R2/25 & CACUUUCACUUCUCCCUUUCAGCGC \\
\hline 6 & R3/25 & AUGACAUAGGCGCGCUGAAAGGGAG \\
\hline 7 & R4/94 * & $\begin{array}{l}\text { GGGAGGACGAUGCGGACCGAAAAAGACCUGACUUCUAUACUAAGUCUA } \\
\text { CGUUCCCAGACGACUCGCCCGAGAAUUAAAUGCCGCGCAUGACCAG }\end{array}$ \\
\hline
\end{tabular}


Table 2. Structures of double-stranded RNA substrates used in this study.

\begin{tabular}{|c|c|c|c|c|}
\hline Name of RNA duplexes & $\begin{array}{c}\text { Oligonucleotide } \\
\text { used }\end{array}$ & \multicolumn{3}{|c|}{$\begin{array}{c}\text { Structure } \\
\left({ }^{\star}\right) \text { radioactive - labeled position }\end{array}$} \\
\hline Blunt-end dsRNA 47R/47R & $1+2$ & $*$ & & \\
\hline Blunt-end dsRNA $25 R / 25 R$ & $3+4$ & $* \quad 25$ bp & & \\
\hline 3'-tail dsRNA 47R/25R1 & $1+3$ & $25 \mathrm{bp}$ & or & $25 \mathrm{bp}$ \\
\hline 5'-tail dsRNA 47R/25R2 & $1+5$ & $* \frac{25 \text { bp }}{22 \mathrm{nt}}$ & or & $\begin{array}{c}25 \text { bp } \\
22 \mathrm{nt}\end{array}$ \\
\hline Two overhang 47R/25R3 & $1+6$ & 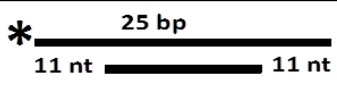 & $c$ & $\frac{25 \mathrm{bp}}{1 \mathrm{nt} \underset{ }{21} \mathrm{nt}}$ \\
\hline
\end{tabular}

\subsection{RNA-dependent ATP hydrolysis assay}

CshA $(1 \mu \mathrm{M})$ was added to a reaction mixture containing $50 \mathrm{mM}$ Tris- $\mathrm{HCl}, \mathrm{pH} 7.5,25 \mathrm{mM} \mathrm{NaCl}, 5 \mathrm{mM}$ $\mathrm{MgCl}_{2}, 2 \mathrm{mM}$ DTT, and $200 \mu \mathrm{M}$ ATP spiked with $0.6 \mu \mathrm{Ci}$ of $\left[\gamma_{-}{ }^{32} \mathrm{P}\right]$ ATP $(3,000 \mathrm{Ci} / \mathrm{mmol}$, GE Healthcare $)$ in the presence or absence of $1 \mu \mathrm{M}$ of various RNA substrates (single-stranded RNAs [ssRNAs]: R1, R0, and R4; double-stranded RNAs [dsRNAs]: blunt-ended 47R/47R, 5'-tail 47R/25R2, and 3'-tail 47R/25R1). The reaction mixtures $(20 \mu \mathrm{L})$ were incubated at room temperature for $0.1,0.5,1,2,5,10,15,20,30,45$, and $60 \mathrm{~min}$, respectively. At each designated time point, the reaction was stopped by the addition of $1 \mu \mathrm{L}$ of $4 \mathrm{M}$ formic acid to each aliquot $(1.5 \mu \mathrm{L})$ of reaction mixture. The quenched reaction aliquot $(1 \mu \mathrm{L})$ was blotted on polyethyleneimine cellulose for thin-layer chromatography (Macherey-Nagel, Düren, Germany) and developed in $0.4 \mathrm{M}$ potassium phosphate, $\mathrm{pH}$ 3.4. Unreacted ATP and product $\mathrm{P}_{\mathrm{i}}$ were separated and quantified using a phosphor imager and OptiQuant/Cyclone software (Packard Instrument Co.).

\subsection{Duplex RNA unwinding assay}

For the duplex RNA unwinding assay, $100 \mathrm{nM}$ CshA and $10 \mathrm{nM}$ of each ${ }^{32} \mathrm{P}$-labeled duplex RNA substrate (blunt-ended 25R/25R, blunt-ended 47R/47R, 3'-tail 47R/25R1，5'-tail 47R/25R2, two-overhang 47R/25R3; see Table 2) were mixed in a buffer containing $50 \mathrm{mM}$ Tris- $\mathrm{HCl}$ (pH 7.5), $25 \mathrm{mM} \mathrm{NaCl}, 2 \mathrm{mM}$ DTT, $0.15 \mathrm{mg} / \mathrm{mL}$ BSA, $5 \mathrm{mM} \mathrm{MgCl}$, and $1 \mu \mathrm{M}$ trap RNA (unlabeled RNA strand used to anneal to the displaced strand of duplex RNA substrates), in the presence or absence of $5 \mathrm{mM}$ ATP. The duplex RNA unwinding reactions were incubated at room temperature for $15 \mathrm{~min}$, and were stopped by adding an equal volume of the quenching buffer (100 mM EDTA, pH 8.0, 0.4\% SDS, 20\% glycerol, $0.1 \%$ bromophenol blue, and $0.1 \%$ xylene cyanol). The dsRNAs and ssRNAs were resolved by native (urea-free) PAGE (15\%). Control size markers corresponding to unwound products were produced by heating each duplex substrate with 600-fold of trap RNA at $95{ }^{\circ} \mathrm{C}$. Radioactivity was quantified using a Cyclone phospho imager (PerkinElmer) and analyzed using OptiQuant/Cyclone software (Packard Instrument Co.).

\subsection{Ribonuclease assay}

For the ribonuclease assay, $0.25 \mu \mathrm{M}$ CshA was mixed with $30 \mathrm{nM}$ of ${ }^{32} \mathrm{P}$-labeled ssRNA or dsRNA substrates in a buffer containing $50 \mathrm{mM}$ Tris- $\mathrm{HCl}(\mathrm{pH} 7.5), 25 \mathrm{mM} \mathrm{NaCl}, 2 \mathrm{mM}$ DTT, $0.15 \mathrm{mg} / \mathrm{mL}$ BSA, and $5 \mathrm{mM} \mathrm{MgCl}_{2}$ at room temperature. After various designated time points, the reaction was stopped by adding of an equal volume of the quenching buffer used in the RNA unwinding assay. The quenched reaction mixtures were loaded onto a $15 \%$ polyacrylamide/ $8 \mathrm{M}$ urea denaturing gel and resolved by PAGE. Radioactivity was visualized using a Cyclone (PerkinElmer) and analyzed by OptiQuant/Cyclone software. Size markers for RNA cleavage was prepared by degrading the ssRNA substrate by alkaline hydrolysis or by using RNase T1, which cleaves ssRNA at guanosine residues [16]. For the alkaline hydrolysis of ssRNA, $60 \mathrm{nM}$ of the 5'-end-labeled ssRNA substrate (47-mer) mixed with $25 \mathrm{mg} / \mathrm{mL}$ yeast tRNA (Invitrogen, CA, USA) was incubated in alkaline hydrolysis buffer (Ambion, Austin, TX, USA) to create a pool of RNA 
ladders which was heated to $95{ }^{\circ} \mathrm{C}$ for 10 min before use. A guanosine residue-specific size marker was generated by degradation of 5'-labeled ssRNA substrate with RNase T1 (Ambion) as follows: 0.5 U RNase $\mathrm{T} 1$ and $30 \mathrm{nM}$ of the labeled ssRNA substrate were incubated at room temperature for $5 \mathrm{~min}$, and then the reaction was stopped by heating at $85^{\circ} \mathrm{C}$ for $5 \mathrm{~min}$.

\section{RESULTS AND DISCUSSION}

\subsection{Duplex RNA stimulates ATP hydrolysis by S. aureus CshA}

A

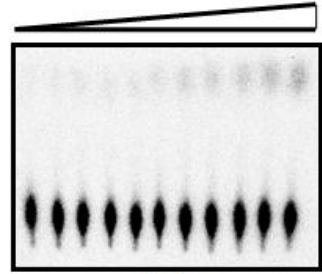

(a)

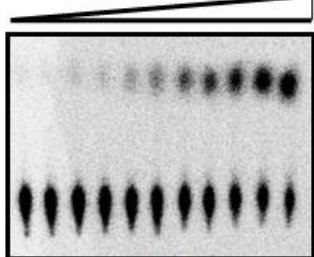

(e)

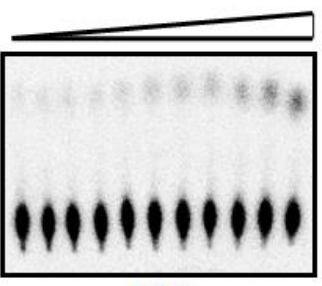

(b)

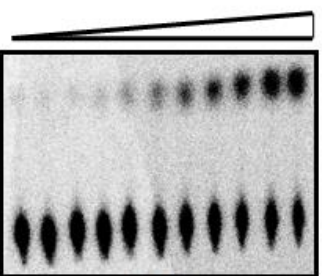

(f)

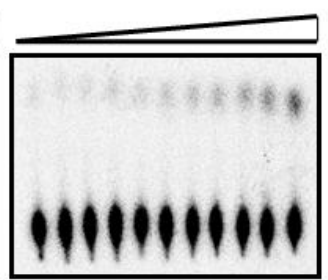

(c)

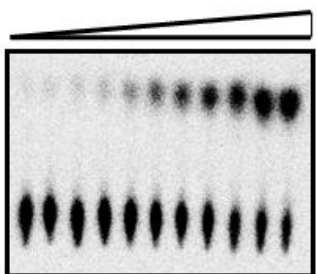

(g)

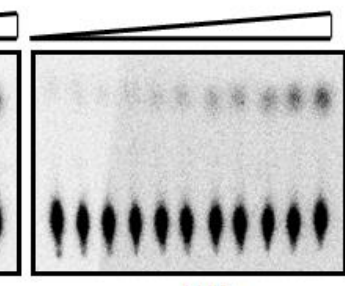

(d) Time

B

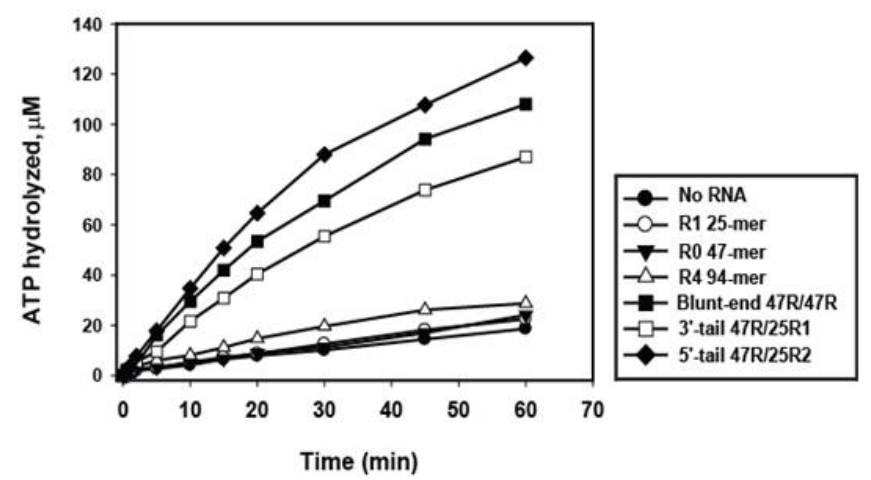

Figure 1. RNA-dependent ATP hydrolysis by S. aureus CshA. (A) Thin layer chromatography analysis of ATP hydrolysis reaction without RNA substrate (a) and various RNA substrates such as ssRNA 25 mer (b), ssRNA 47 mer (c), ssRNA 94 mer (d), blunt-end dsRNA (e), 3'-tail dsRNA (f), 5'-tail dsRNA (g). (B) Time course of RNAdependent ATP hydrolysis by CshA in the presence or absence of various RNA ligands. ATP $(200 \mu \mathrm{M})$ spiked with [ $\gamma$-32P] ATP was incubated with $1 \mu \mathrm{M}$ of CshA for various time points with or without RNA ligand $(1 \mu \mathrm{M})$ at room temperature. Products of ATP hydrolysis were analyzed on polyethyleneimine-cellulose thin-layer chromatography and quantified by measuring radioactivity. The progress of ATP hydrolysis by CshA is represented in the graph as concentration of ATP hydrolyzed.

The S. aureus DEAD-box protein CshA was predicted to be an ATP-dependent RNA helicase. It was thus necessary to determine whether CshA contained the presumed ATP hydrolysis activity and whether the type of RNA substrate used would affect the ATP hydrolysis activity. To address these questions, ATP hydrolysis by CshA was examined in the presence or absence of several ssRNAs of different lengths or dsRNAs with different terminal structures. Then, the time course of ATP hydrolysis by CshA in the presence of each RNA ligand was quantified (Fig. 1). The results show that ATP hydrolysis by CshA was significantly stimulated by dsRNA ligands. Differences in RNA duplex structures slightly affected the ATPase activity. Although both dsRNA ligands (47R/25R1 and 47R/25R2) contained a 25 bp duplex region 
and a 22 nt single-stranded tail, the position of the single-stranded tail (i.e., at the $5^{\prime}$ end or the $3^{\prime}$ end of the duplex) affected ATP activity: ATP hydrolysis by CshA was more efficient in the presence of dsRNA with a $5^{\prime}$ tail $(47 \mathrm{R} / 25 \mathrm{R} 1)$ than in the presence of dsRNA with a $3^{\prime}$-tail $(47 \mathrm{R} / 25 \mathrm{R} 2 ; 60$ min incubation). Interestingly, blunt-ended dsRNA, which was known to be an unfavorable substrate for DEAD-box proteins, enhanced ATP hydrolysis by approximately 6-fold as compared with ATP hydrolysis in the absence of an RNA ligand. In contrast, the effect of ssRNAs on ATP hydrolysis by CshA was insignificant, although ATPase activity was slightly stronger in the presence of long ssRNA ligands than in the presence of short ssRNAs. This observation could be explained by the formation of hairpin structure or selfcomplementarity in long ssRNA substrates.

Like most DEAD-box proteins, CshA catalyzes ATP hydrolysis in the presence of RNA ligands $[17,18]$. We observed that the RNA-dependent ATP hydrolysis activity of CshA was affected by RNA structure (Fig. 1A): RNA substrates containing duplex structure stimulated ATP hydrolysis activity more than ssRNA substrates did. Similar dsRNA-dependent ATPase activity has been reported for several DEAD-box proteins such as the human DEAD-box protein Ddx42p [19] and p68 RNA helicase [20]. In addition, the bacterial DEAD-box protein RhlE was shown to possess RNA-dependent ATPase activity that was stimulated not only by duplexes with either $3^{\prime}$ or $5^{\prime}$ overhangs but also by blunt-ended RNA duplexes [21]. In contrast, $E$. coli DEAD-box proteins such as Ded1, CsdA, and SrmB did not catalyze ATP hydrolysis in the presence of a blunt-ended RNA duplex [21, 22].

\subsection{S. aureus CshA is unable to catalyze RNA unwinding}

A

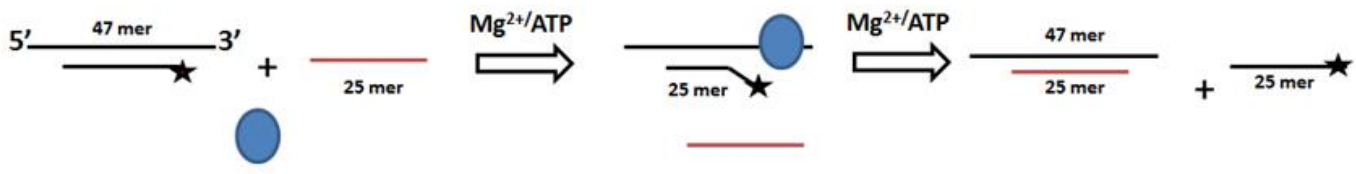

B

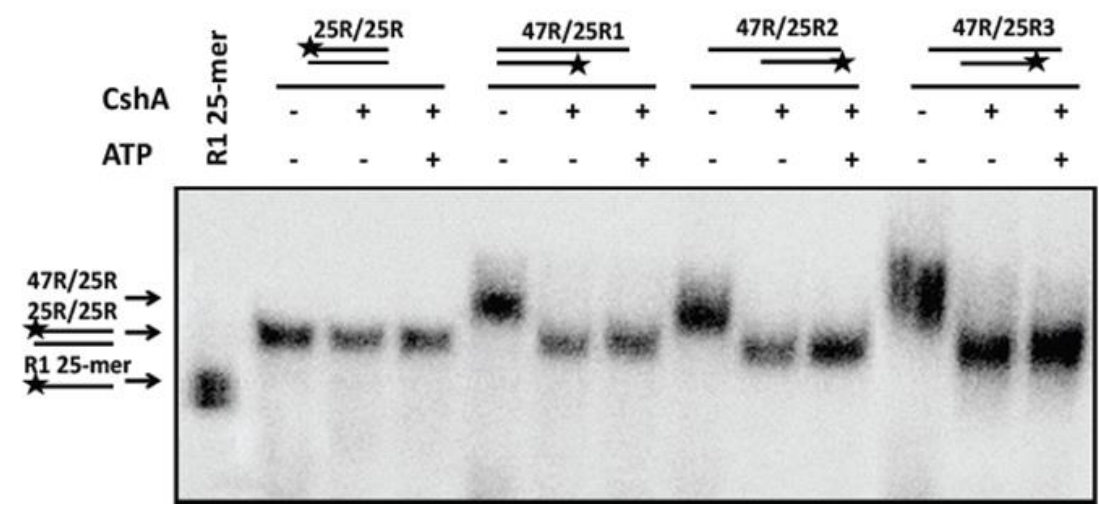

Figure 2. RNA duplex unwinding by Staphylococcus aureus CshA. (A) Schematic diagram of unwinding assay. (B) Representative PAGE image of duplex RNA unwinding by CshA with various RNA substrates. Each 32P-labeled duplex RNA substrate $(10 \mathrm{nM})$ and $1 \mu \mathrm{M}$ unlabeled single-stranded RNA as a trap (i.e., R1 for 25R/25R, R1 for $47 \mathrm{R} / 25 \mathrm{R} 1, \mathrm{R} 2$ for $47 \mathrm{R} / 25 \mathrm{R} 2$, and $\mathrm{R} 3$ for $47 \mathrm{R} / 25 \mathrm{R} 3$ ) were incubated with $0.1 \mu \mathrm{M}$ CshA in the presence or absence of ATP $(5 \mathrm{mM})$ for $15 \mathrm{~min}$ at room temperature. The reaction products were analyzed with $15 \%$ nondenaturing

PAGE. Asterisks indicate the positions of radiolabels.

Several types of duplex RNA substrates were prepared (Table 2): blunt-ended 25 bp duplex RNA $(25 \mathrm{R} / 25 \mathrm{R})$ and $25 \mathrm{bp}$ duplex RNA with a $22 \mathrm{nt}$ tail at the $3^{\prime}$ end $(47 \mathrm{R} / 25 \mathrm{R} 1)$, the $5^{\prime}$ end $(47 \mathrm{R} / 25 \mathrm{R} 2)$, or 11 nt tail at both ends (47R/25R3) to determine the RNA duplex unwinding activity of CshA. The unwinding reactions were carried out by incubating CshA $(100 \mathrm{nM})$ with each ${ }^{32} \mathrm{P}$-labeled duplex RNA substrate (10 
nM) supplemented with the trap RNA $(1 \mu \mathrm{M})$ in the presence or absence of ATP $(5 \mathrm{mM})$. If CshA possessed RNA helicase activity, ${ }^{32} \mathrm{P}$-labeled ssRNA should be displaced from duplex RNA in the presence of ATP. However, the results on the native gel indicated that CshA was unable to displace the ${ }^{32} \mathrm{P}$-labeled ssRNA from any type of duplex RNA (Fig. 2). Control experiments in the absence of CshA or ATP showed no unwinding, indicating that the $25 \mathrm{bp}$ duplex is not spontaneously unwound under our assay conditions. In addition, CshA had no catalytic activity on blunt-ended dsRNA substrate in the presence of ATP. However, CshA produced blunt-ended RNA duplexes instead of ssRNA as the unwinding product when incubated with dsRNA substrates containing overhangs $\left(5^{\prime}, 3^{\prime}\right.$, or both) in the presence or absence of ATP. The fact that the same products were formed in the unwinding reactions regardless of the presence of ATP prompted us to hypothesize that CshA degrades the single-stranded regions in the RNA duplexes and does not affect the blunt ends.

Although CshA was predicted to be a putative ATP-dependent RNA helicase, S. aureus CshA did not show any RNA unwinding activity under our experimental conditions. Thus, it may be that CshA either does not possess intrinsic RNA unwinding activity or requires unknown cofactor(s) for RNA helicase activity [23]. RNA duplexes containing distinct sequences with appropriate length, structure, or thermal stability have a significant influence on the RNA unwinding activity of DEAD-box proteins [24-26]. However, protein cofactors would be probably required for optimal helicase activity, as is the case for the DEAD-box protein elF4A, which only shows RNA helicase activity in the presence of the RNA-binding protein elF4B [27]. Likewise, it has been reported that yeast Dbp5p does not catalyze RNA unwinding in a conventional helicase assay in vitro unless isolated from cell extracts by immunoprecipitation [28]. Thus, it is plausible that the reaction conditions used in our study of RNA unwinding were not sufficient to reveal RNA unwinding activity in CshA.

\subsection{S. aureus CshA possesses ribonuclease activity}

The finding that duplex RNAs with overhangs treated with CshA migrated to the same position in the gel as blunt-ended dsRNA led us to investigate whether CshA possessed ribonuclease activity. We tested degradation of the same duplex RNA substrates used in the unwinding assay, except that the ssRNA was labeled with ${ }^{32} \mathrm{P}$ at the $5^{\prime}$ end. Half of the reaction mixture was loaded on a nondenaturing polyacrylamide gel and the other half on a denaturing polyacrylamide gel. If CshA preferentially degraded the singlestranded regions of the dsRNA substrates, the resulting products would be shortened RNA fragments of blunt-ended dsRNA; the nondenaturing PAGE would retain the RNA fragments as duplexes, while the denaturing PAGE would dissociate the duplex RNA fragment into ssRNA components (Fig. 3A).

Analysis using both nondenaturing and denaturing PAGE, shown in Fig. 3B and 3C, respectively, revealed that no RNA degradation products formed when the blunt-ended dsRNA substrate (47R/47R) was used. In contrast, when dsRNA substrates containing 5 ' overhangs (47R/25R2 and 47R/25R3) were incubated with CshA, the protein cleaved the single-stranded region of RNA duplexes to form short RNA fragments (Fig. 3B and C). Additionally, when RNA duplexes with 3' overhangs (47R/25R1) were used, the size of the reaction products separated on nondenaturing PAGE corresponded to that of the blunt-ended RNA duplex 25R/25R (Fig. 3B) and was resolved into 25-mer ssRNA on the denaturing polyacrylamide gel (Fig. 3C). These results demonstrate that CshA could cleave the single-stranded region of an RNA duplex to form blunt-ended dsRNA, but it could not degrade blunt-ended dsRNA. Although the same pattern of RNA degradation was observed in reactions with or without ATP, CshA seemingly displayed enhanced cleavage of RNA substrates in the presence of ATP.

RNA degradation by CshA is consistent with a presumed role in the gram-positive degradosome, in which CshA has been known to interact with several components [13]. Recently, inactivation of $c s h A$ in $S$. aureus has been shown to result in dysregulation of biofilm formation, which was required for protection from the immune system and antibiotic treatment, owing to a deficient modulation of mRNA stability via the RNA degradosome [29]. Previously, it was thought that CshA, via sequence-specific interactions, presented target RNAs for degradation by RNases [29]. However, our results showed that CshA could degrade ssRNA in the presence of $\mathrm{Mg}^{2+}$-ATP without the need for any other cofactor(s). It is thus more likely that CshA participates in the RNA turnover machinery by resolving inhibitory RNA secondary structure in preparation for RNA degradation activity. Further experiments will be necessary to verify the function of CshA in the presence of one or more components of the putative degradosome. 
A

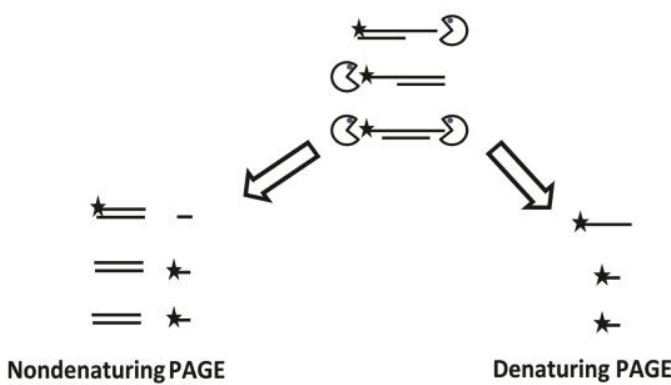

B

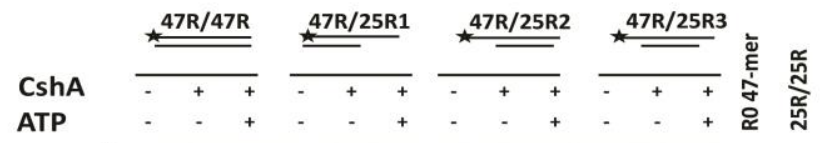

C
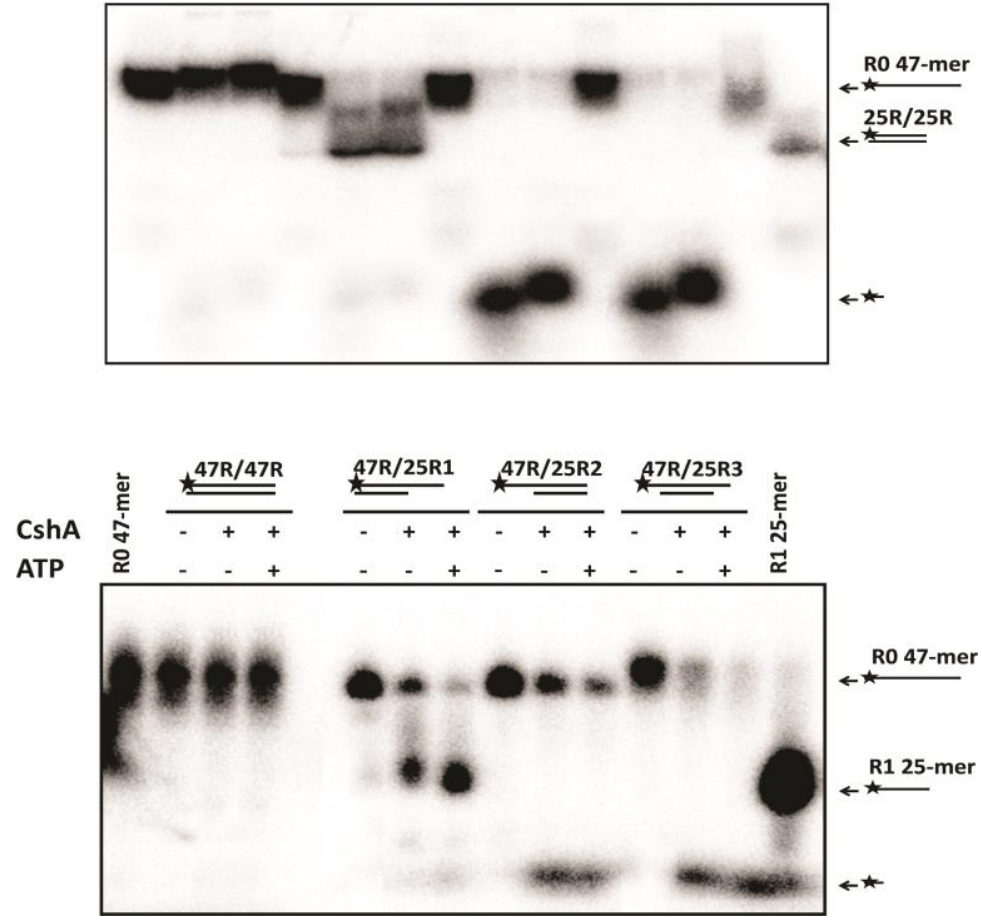

Figure 3. CshA degrades the single-stranded RNA region of duplex RNA substrates. (A) Schematic diagram of ribonuclease assay with various 32P-labeled RNA duplexes and analysis of degraded RNA products with either nondenaturing or denaturing PAGE. Reactions were carried out by incubation of $10 \mathrm{nM} 32 \mathrm{P}$-labeled duplex RNA

substrates with $0.1 \mu \mathrm{M}$ CshA in the presence or absence of $5 \mathrm{mM}$ ATP for $15 \mathrm{~min}$ at room temperature.

Subsequently, the reactions were divided into 2 parts. One part was analyzed on $15 \%$ nondenaturing PAGE; the other part was analyzed on $10 \%$ denaturing (8 M urea) PAGE. (B, C) Representative nondenaturing and denaturing

PAGE analysis of degraded RNA products from various RNA duplexes, respectively. Asterisks indicate the positions of radiolabels.

\section{CONCLUSION}

The present study showed that the $S$. aureus DEAD-box protein CshA possesses endoribonuclease activity. It will be intriguing to biochemically investigate how the different ATP-dependent and ATP-independent activities contribute to the role of CshA as an RNA remodeling factor in the RNA degradosome. To the best of our knowledge, a DEAD-box protein has been implicated in multiple ATP-independent activity for the first time, including RNA degradation in a pathogenic bacterium. 


\section{ACKNOWLEDGLEMENT}

This study were carried out at Nucleic Acid Biochemistry Laboratory and Global Laboratory, Konkuk University, Seoul, Korea. Therefore, I would like to sincerely thank Professor Kim Dong-Eun and Professor Kang Lin-Woo for creating favorable conditions to conduct this research.

\section{REFERENCES}

1. Linder, P., Dead-box proteins: a family affair--active and passive players in RNP-remodeling. Nucleic Acids Res, 2006. 34(15): p. 4168-80.

2. Rocak, S. and P. Linder, DEAD-box proteins: the driving forces behind RNA metabolism. Nat Rev Mol Cell Biol, 2004. 5(3): p. 232-41.

3. de la Cruz, J., D. Kressler, and P. Linder, Unwinding RNA in Saccharomyces cerevisiae: DEAD-box proteins and related families. Trends Biochem Sci, 1999. 24(5): p. 192-8.

4. Hiramatsu, K., et al., Methicillin-resistant Staphylococcus aureus clinical strain with reduced vancomycin susceptibility. J Antimicrob Chemother, 1997. 40(1): p. 135-6.

5. Hiramatsu, K., et al., Dissemination in Japanese hospitals of strains of Staphylococcus aureus heterogeneously resistant to vancomycin. Lancet, 1997. 350(9092): p. 1670-3.

6. Kuroda, M., et al., Whole genome sequencing of meticillin-resistant Staphylococcus aureus. Lancet, 2001. 357(9264): p. 1225-40.

7. Ohta, T., et al., Nucleotide substitutions in Staphylococcus aureus strains, Mu50, Mu3, and N315. DNA Res, 2004. 11(1): p. 51-6.

8. Hunger, K., et al., Cold-induced putative DEAD box RNA helicases CshA and CshB are essential for cold adaptation and interact with cold shock protein B in Bacillus subtilis. J Bacteriol, 2006. 188(1): p. 240-8.

9. Costerton, J.W., P.S. Stewart, and E.P. Greenberg, Bacterial biofilms: a common cause of persistent infections. Science, 1999. 284(5418): p. 1318-22.

10. Seufferheld, M.J., H.M. Alvarez, and M.E. Farias, Role of polyphosphates in microbial adaptation to extreme environments. Appl Environ Microbiol, 2008. 74(19): p. 5867-74.

11. Koerdt, A., et al., Crenarchaeal biofilm formation under extreme conditions. PLoS One, 2010. 5(11): p. e14104.

12. Baker-Austin, C., et al., Biofilm development in the extremely acidophilic archaeon 'Ferroplasma acidarmanus' Fer1. Extremophiles, 2010. 14(6): p. 485-91.

13. Roux, C.M., J.P. DeMuth, and P.M. Dunman, Characterization of components of the Staphylococcus aureus mRNA degradosome holoenzyme-like complex. J Bacteriol, 2011. 193(19): p. 5520-6.

14. Lee, S.Y., et al., Cloning, purification, crystallization and preliminary X-ray crystallographic analysis of the Nterminal domain of DEAD-box RNA helicase from Staphylococcus aureus strain Mu50. Acta Crystallogr Sect F Struct Biol Cryst Commun, 2010. 66(Pt 12): p. 1674-6.

15. Jang, K.J., et al., Isolation of inhibitory RNA aptamers against severe acute respiratory syndrome (SARS) coronavirus NTPase/Helicase. Biochem Biophys Res Commun, 2008. 366(3): p. 738-44.

16. Tezias, S.S., et al., Cloning and characterization of polyA- RNA transcripts encoded by activated B1-like retrotransposons in mouse erythroleukemia MEL cells exposed to methylation inhibitors. BMB Rep, 2012. 45(2): p. 126-31.

17. Cordin, O., et al., The DEAD-box protein family of RNA helicases. Gene, 2006. 367: p. 17-37. 
18. Iost, I. and M. Dreyfus, DEAD-box RNA helicases in Escherichia coli. Nucleic Acids Res, 2006. 34(15): p. 4189-97.

19. Uhlmann-Schiffler, H., C. Jalal, and H. Stahl, Ddx42p--a human DEAD box protein with RNA chaperone activities. Nucleic Acids Res, 2006. 34(1): p. 10-22.

20. Huang, Y. and Z.R. Liu, The ATPase, RNA unwinding, and RNA binding activities of recombinant p68 RNA helicase. J Biol Chem, 2002. 277(15): p. 12810-5.

21. Bizebard, T., et al., Studies on three E. coli DEAD-box helicases point to an unwinding mechanism different from that of model DNA helicases. Biochemistry, 2004. 43(24): p. 7857-66.

22. Iost, I., M. Dreyfus, and P. Linder, Ded1p, a DEAD-box protein required for translation initiation in Saccharomyces cerevisiae, is an RNA helicase. J Biol Chem, 1999. 274(25): p. 17677-83.

23. Silverman, E., G. Edwalds-Gilbert, and R.J. Lin, DExD/H-box proteins and their partners: helping RNA helicases unwind. Gene, 2003. 312: p. 1-16.

24. Yang, Q., et al., DEAD-box proteins unwind duplexes by local strand separation. Mol Cell, 2007. 28(2): p. 25363.

25. Stampfl, S., et al., Characterization of the kinetics of RNA annealing and strand displacement activities of the E. coli DEAD-box helicase CsdA. RNA Biol, 2013. 10(1): p. 149-56.

26. Rogers, G.W., Jr., N.J. Richter, and W.C. Merrick, Biochemical and kinetic characterization of the RNA helicase activity of eukaryotic initiation factor 4A. J Biol Chem, 1999. 274(18): p. 12236-44.

27. Rozen, F., et al., Bidirectional RNA helicase activity of eucaryotic translation initiation factors $4 \mathrm{~A}$ and $4 \mathrm{~F}$. Mol Cell Biol, 1990. 10(3): p. 1134-44.

28. Tseng, S.S., et al., Dbp5p, a cytosolic RNA helicase, is required for poly(A)+ RNA export. EMBO J, 1998. 17(9): p. 2651-62.

29. Oun, S., et al., The CshA DEAD-box RNA helicase is important for quorum sensing control in Staphylococcus aureus. RNA Biol, 2013. 10(1): p. 157-65.

\section{PROTEIN DEAD-BOX CSHA TÙ VI KHUẨN Staphylococcus aureus Mu 50 THỂ HIỆN HOẠT TÍNH RIBONUCLEASE}

Tóm tắt: Protein DEAD-box đóng vai trò quan trọng trong nhiều quá trình RNA, từ tổng hợp RNA đến phân hủy RNA. Hơn nữa, đã có báo cáo cho thấy một số protein DEAD của vi khuẩn là thành phần của RNA degradosome và không phân cắt RNA trực tiếp. Tuy nhiên, vai trò của protein DEAD trong sự phân hủy RNA chưa được hiểu rõ. Trong nghiên cứu này, chúng tôi đã chứng minh rằng protein DEAD-box CshA từ chủng Staphylococcus aureus kháng vancomycin Mu50 sở hữu hoạt tính ribonuclease, phân hủy RNA. Mặc dù CshA thể hiện hoạt tính ATPase phụ thuộc RNA nhưng CshA lại không thể hiện hoạt tính tháo xoắn mạch RNA trong điều kiện phòng thí nghiệm. Thay vào đó, CshA đã xúc tác cho sự phân hủy của mạch đơn RNA trong các cơ chất mạch đôi RNA để hình thành nên sản phẩm là các RNA mạch đôi đầu bằng (blunt-end RNA). Do đó, hoạt tính ribonuclease của protein DEAD-box CshA có thể góp phần tái cấu trúc RNA trong các RNA degosome của vi khuẩn. Nghiên cứu này là báo cáo đầu tiên về protein DEAD-box từ vi khuẩn gây bệnh có liên quan đến hoạt tính không phụ thuộc ATP trên có chất RNA như sự phân hủy RNA.

Từ khóa: DEAD-box Protein, CshA, ribonuclease, RNA helicase, Staphylococcus aureus.

Ngày nhận bài: 11/03/2020

Ngày chấp nhận đăng: 21/04/2020 